\title{
ВНУТРИВИДОВАЯ ИЗМЕНЧИВОСТЬ ЭЛЕМЕНТНОГО СОСТАВА ЯРОВОЙ МЯГКОЙ ПШЕНИЦЫ И ЕЕ СВЯЗЬ С УРОЖАЙНОСТЬЮ И ПОВРЕЖДЕНИЕМ ЛИСТЬЕВ ВРЕДИТЕЛЯМИ Л.Е. Колесников ${ }^{1 *}$, Е.Б. Подгорная ${ }^{2}$, О.Н. Танюхина ${ }^{2}$, О.И. Бурова ${ }^{2}$ Ю.Р. Колесникова ${ }^{3}$ \\ ${ }^{1}$ Санкт-Петербургский государственный аграрный университет;
}

${ }^{2}$ Научно-исследовательский институт гигиены, профпатологии и экологии человека Федерального медико-биологического агентства;

${ }^{3}$ Всероссийский научно-исследовательский институт растениеводства им. Н.И. Вавилова, Санкт-Петербург, Россия

* Эл.noчma: kleon9@yandex.ru

Статья поступила в редакцию 10.04.2014; принята к печати 20.10.2014

На урожайность сельскохозяйственных культур, в том числе пшеницы, и на их устойчивость к вредителям влияет элементный состав растений. Отклонения от норм содержания химических элементов в пшенице могут быть вызваны экологическими, климатогеографическими, биологическими факторами и ее сортовыми особенностями. В статье представлены результаты определения содержания 20 химических элементов из числа тяжелых и легких металлов и металлоидов в зернах 31 образца яровой мягкой пшеницы в сопоставлении с 10 показателями структуры урожая и повреждения листьев личинками пьявицы обыкновенной. Отмечено положительное влияние увеличения содержания калия, скандия, меди на большинство рассматриваемых показателей структуры урожая пшеницы. Выявлено снижение повреждения листьев пшеницы личинками пьявицы обыкновенной при увеличении содержания в зернах кадмия, свинца, висмута, марганца, которые относятся к тяжелым металлам и являются токсичными для различных групп живых организмов, а также при увеличении уровня селена.

Ключевые слова: яровая мягкая пшеница, химические элементы, урожайность, пьявица обыкновенная.

\section{INTRASPECIES VARIABILITY OF THE ELEMENTAL COMPOSITION OF SOFT SPRING WHEAT AS ASSOCIATED WITH CROP PRODUCTIVITY AND PEST-CAUSED DAMAGE TO FOLIAGE}

L.Ye. Kolesnikov ${ }^{1 *}$, Ye.B. Podgornaya², O.N. Taniukhina ${ }^{2}$, O.I. Burova², Yu.R. Kolesnikova ${ }^{3}$ ${ }^{1}$ Saint-Petersburg Agrarian University;

${ }^{2}$ Research Institute of Hygiene, Occupational Diseases and Human Ecology of the Federal Medico-Biological Agency;

${ }^{3}$ N.I. Vavilov All-Russia Research Institute of Plant Cultivation, Saint Petersburg, Russia *E-mail: kleon9@yandex.ru

Productivity of crops, including wheat, and their resistance to pests are influenced by the contents of chemical elements in plants. Deviations of the contents from their normal values may be caused by ecological, geographic, meteorological, and bilogical factors as well by crop variety-specific internal features. The present paper reports the results of determination of 20 elements referred to light and heavy metals and metalloids in the grain of 31 varieties of soft spring wheat and their comparison with 10 parameters of the structure of crop productivity and with the extent of damage to foliage caused by cereal leaf beetle (Lema melanopus $\mathbf{L}$.) larvae. Increase contents of potassium, scandium, and copper were found to positively correlate on the majority of parameters of crop productivity. Decreases in damage to foliage were found upon increases in the contents of cadmium, lead, bismuth, and manganese, which are referred to heavy metals known to be toxic to different a wide range of organisms, and upon an increase in selenium content.

Keywords: soft spring wheat, chemical elements, cop productivity, cereal leaf beetle.

\section{Введение}

Загрязнение природной среды прямо или косвенно влияет на распределение химических элементов и соединений в воздушной и водной среде, почвах и биологических объектах, в частности растениях $[4,21]$.

Стабильность элементного состава живых организмов является одним из главных условий их нормального функционирования [18]. Изменения содержания ряда химических элементов в растениях, вызванные экологическими, климатогеографическими факто- рами, антропогенной трансформацией среды, может отражаться на их урожайности и устойчивости к вредителям.

Азот, фосфор, калий, кальций, магний, сера и железо нужны в относительно больших количествах. Микроэлементы: бор, марганец, медь, цинк, молибден, кобальт, ванадий, селен, йод - необходимы в очень малых дозах $[10,19]$. Микроэлементы входят в состав коферментов и пигментов, и их недостаток нарушает нормальный рост и развитие растений, вы- 
зывает нарушения углеводного и азотного обмена, синтеза белковых веществ, снижает устойчивость растений к засухе, воздействию низких и высоких температур и заболеваниям [19].

К тяжёлым металлам относят элементы с атомной массой свыше 50 дальтон: $\mathrm{V}, \mathrm{Cr}, \mathrm{Mn}, \mathrm{Fe}, \mathrm{Co}, \mathrm{Ni}, \mathrm{Cu}$, $\mathrm{Zn}, \mathrm{Mo}, \mathrm{Cd}, \mathrm{Sn}, \mathrm{Hg}, \mathrm{Pb}, \mathrm{Bi}$ и др. [18]. Источниками ионов тяжелых металлов в сельскохозяйственном производстве являются главным образом минеральные удобрения. Наиболее существенными как по набору, так и по концентрациям тяжелых металлов являются фосфорные удобрения, а также удобрения, получаемые с использованием экстракционной кислоты (аммофосы, аммофоски, нитрофоски, суперфосфаты). Простой суперфосфат является источником кадмия [20]. Кроме кадмия (150-170 мг/кг) в нем содержатся хром (66-243 мг/кг), кобальт (0,1-90 мг/кг), медь (4-79 мг/кг), никель (7-32 мг/кг), ванадий (70-180 мг/кг) и цинк (50-1430 мг/кг) [3].

Пшеница - одна из важнейших стратегических зерновых культур, на долю которой приходится около трети мирового производства зерна, обеспечивающего продовольствием более половины населения земного шара. В Российской Федерации посевы пшеницы занимают более 25 млн га. Яровая пшеница занимает 55-60\% от общей площади посевов зерновых культур [9].

Одной из актуальных задач растениеводства является оценка продуктивности яровой мягкой пшеницы и определение возможности её реализации в зависимости от влияния агроэкологических факторов с учетом конкретных особенностей районов ее культивирования $[8,12]$. В хозяйствах с неблагоприятным фитосанитарным состоянием посевов яровой пшеницы или при наличии в их окружении неблагополучных земель практически невозможно реализовать в полной мере достижения селекции, семеноводства и прогрессивных технологий [8].

Одним из наиболее распространенных вредителей яровой мягкой пшеницы в основных зерносеющих регионах РФ является пьявица обыкновенная Lema melanopus L. Личинки пьявицы, питаясь листьями пшеницы, не затрагивая жилок, скелетируют листья, что приводит к их засыханию [5].

Целью настоящей работы являлось определение взаимосвязей между элементным составом зерен яровой мягкой пшеницы, показателями структуры урожая и повреждением листьев пьявицей обыкновенной Lema melanopus L.

\section{Материалы и методы}

Исследован 31 образец яровой мягкой пшеницы, предоставленные отделом генетических ресурсов пшеницы Всероссийского научно-исследовательского института растениеводства (ВИР). Эти сорта и линии пшеницы происходят из России (Европейская и Азиатская части); Восточной и Северной Европы, Восточной и Юго-Восточной Азии, Австралии и Новой Зеландии, Северной и Центральной Америки (США, Канада).

Исследования проведены на кафедре защиты и карантина растений Санкт-Петербургского государственного аграрного университета (СПбГАУ) и в лаборатории водной и промышленной экотоксикологии при Научно-исследовательском институте гигиены, профпатологии и экологии человека Федераль- ного медико-биологического агентства (НИИГПЭЧ ФМБА России).

Образцы пшеницы выращивались в 2012 г. на Пушкинских опытных участках ВИРа (рис. 1) в агроэкологических условиях Северо-Западного региона РФ на естественном инфекционном фоне. Почвы опытных участков дерново-подзолистые, легкосуглинистые. Содержание гумуса в пахотном слое 3,5\%. Peакция почвенного раствора слабокислая.

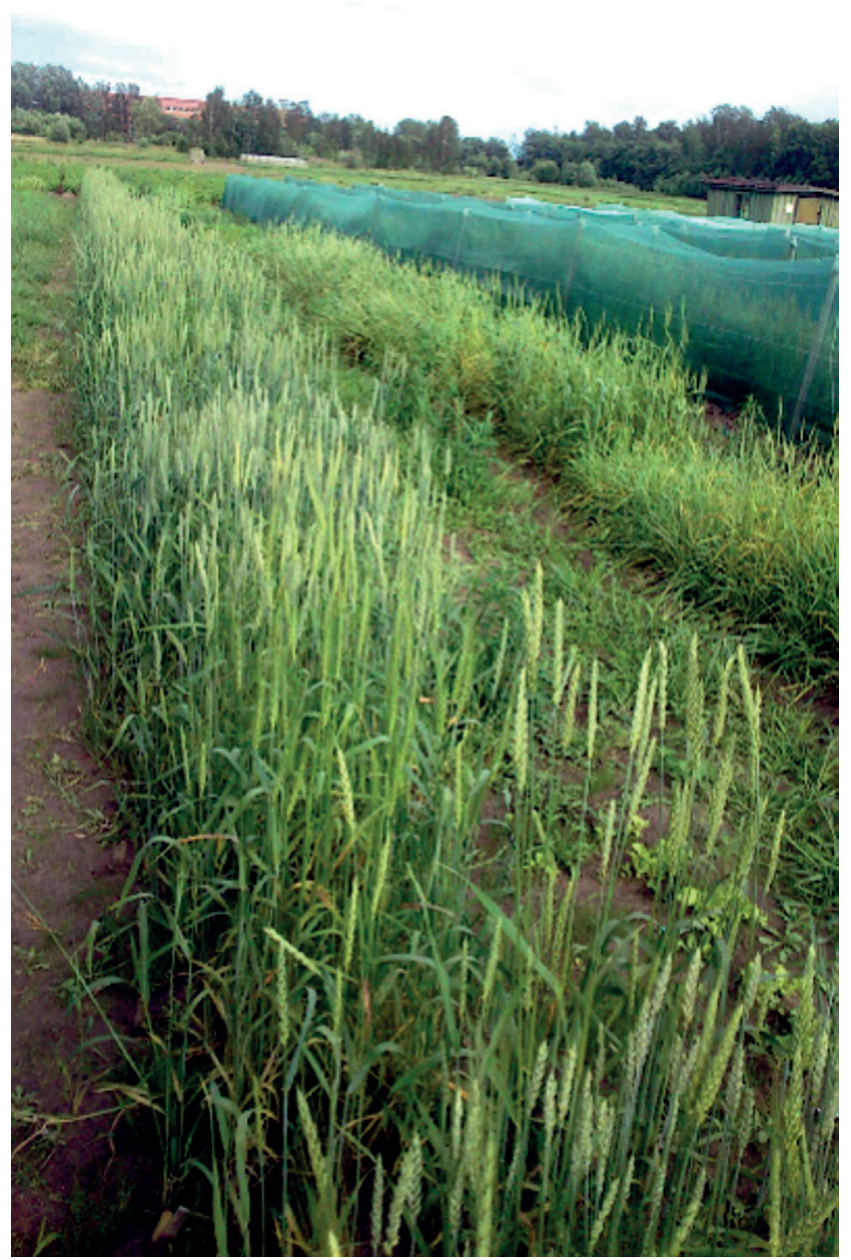

Рис. 1. Посев яровой мягкой пшеницы на опытном поле Пушкинских лабораторий ВИРа

Образцы пшеницы были высеяны на делянках площадью 1,0 м² рядовым способом с междурядьями 15 см и расстоянием в ряду 1-2 см (300 зерен/м²). Глубина заделки семян - 5-6 см. Каждый образец опыта был высеян в 2-кратной повторности.

Содержание 20 химических элементов: $\mathrm{Na}, \mathrm{Mg}, \mathrm{Al}$, $\mathrm{K}, \mathrm{Ca}, \mathrm{Cr}, \mathrm{Mn}, \mathrm{Fe}, \mathrm{Co}, \mathrm{Cu}, \mathrm{Ni}, \mathrm{Se}, \mathrm{Mo}, \mathrm{Ba}, \mathrm{Pb}, \mathrm{Bi}, \mathrm{Sc}$, $\mathrm{As}, \mathrm{Cd}, \mathrm{Tl}$ - в зернах определяли методом масс-спектрального анализа с индуктивно-связанной плазмой (ИСП-МС) на масс-спектрометре Agilent ICP-MS 7700x. Содержание каждого элемента определяли по среднему значению пяти параллельных измерений с использованием программного обеспечения ICP-MS MassHunter. В расчетах использовали средние от результатов, полученных на двух образцах, высеянных в 2-кратной повторности.

Учет повреждений листьев пшеницы личинками пьявицы обыкновенной Lema melanopus L. (рис. 2) осуществляли в конце фазы молочной спелости зерна по числу повреждений на листе и доли (\%) по- 


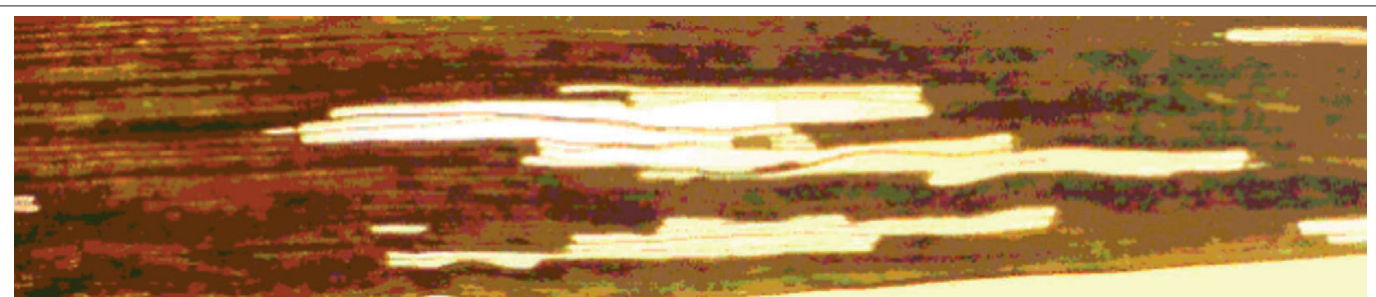

Pис. 2. Симптомы повреждения листьев личинками пьявицы обыкновенной Lema melanopus L.

врежденной площади листа [5]. Площадь каждого повреждения $S$ считали соответствующей площади эллипса с осями $a$ и $b$ (ширина и длина повреждения) и рассчитывали по формуле $S=\pi \times a \times b$.

В соответствии с методическими указаниями [17] определяли следующие показатели структуры урожая: продуктивную и общую кустистость растений пшеницы, их высоту, длину колоса, количество колосков в колосе, количество зерен в колосе и массу 1000 зерен. Потенциальную урожайность сортов яровой пшеницы $\mathrm{Y}_{\mathrm{p}}$. (т/га) рассчитывали по продуктивной кустистости и числу растений, высеянных на $1 \mathrm{~m}^{2}$ :

$$
Y_{\mathrm{p} .}=\mathrm{M}_{\mathrm{K}} \mathrm{K}_{\mathrm{\Pi}} \mathrm{P}_{\mathrm{n}} \times 10000,
$$

где $\mathrm{M}_{\mathrm{K}}$ - масса зерен колоса одного растения (т); $\mathrm{K}_{\text {п }}$ продуктивная кустистость образца; $\mathrm{P}_{\text {п }}-$ плотность посева (число растений на $1 \mathrm{~m}^{2}$ ).

Статистический анализ проводили с использованием программ SPSS 21.0, Excel 2010, Statistica 6.0.

\section{Результаты и их обсуждение}

Результаты сопоставления содержания металлов и металлоидов в зернах с предельно допустимыми концентрациями [2] представлены в табл. 1.
Практически у всех изученных образцов пшеницы найдено превышение ПДК по содержанию $\mathrm{Fe}, \mathrm{Cu}, \mathrm{Cr}$, Cd. Превышение ПДК по содержанию Ni отмечено только в образцах 93-11-2-3-2 и и-616486, а по содержанию $\mathrm{Se}$ - в образцах ОмГАУ 90, и-144683, M 77 1140 и и-616339.

Данные по потенциальной урожайности сортов яровой мягкой пшеницы, сгруппированных по их происхождению, представлены на рис. 3. Наибольшим этот показатель (в среднем 9,12 т/га) оказался у образцов из Восточной Европы: Banti (и-620574), Sirael (и-620336), Septima (и-620337), Séance (и-620338). Элементный состав зерен указанной группы образцов отличался от образцов Российской селекции (Европейской части) (ЛТ 4, и-146754, Мерцана, и-156545, Московская 35, к-48762) достоверно большим содержанием $\mathrm{Na}$ (на 50,6\%); Al (на 59,3\%); Са (на 30,1\%); Со (на 31,4\%); Ва (на 44,4\%); Pb (на $55,2 \%$ ); Sc (на 19,7\%) и сниженными концентрациями $\mathrm{Mg}$ (на 9,25\%); $\mathrm{Mn}$ (на 12,9\%); $\mathrm{Cu}$ (на 28,4\%); $\mathrm{Ni}$ (на $14,9 \%$ ); Se (на 77,7\%); Мо (на 21,8\%).

Наибольшими значениями массы 1000 зерен отличались сорта яровой мягкой пшеницы из Европейской части РФ (ЛТ 4, и-146754; Мерцана, и-156545; Московская 35, к-48762), из Азиатской части РФ (Памяти

Концентрации металлов и металлоидов в зернах яровой мягкой пшеницы

Табл. 1 различного происхождения, выраженные относительно ПДК

\begin{tabular}{|c|c|c|c|c|c|c|c|c|c|}
\hline Происхождение & Al & $\mathbf{F e}$ & $\mathrm{Cu}$ & $\mathrm{Cr}$ & $\mathbf{N i}$ & Se & $\mathbf{P b}$ & As & Cd \\
\hline $\begin{array}{l}\text { Россия, Европейская часть (ЛТ 4, } \\
\text { и-146754, Мерцана, и-156545, } \\
\text { Московская 35, к-48762) }\end{array}$ & $\begin{array}{c}0,27 \\
\pm 0,03\end{array}$ & $\begin{array}{c}1,3 \\
\pm 0,1\end{array}$ & $\begin{array}{c}1,6 \\
\pm 0,0\end{array}$ & $\begin{array}{c}4,1 \\
\pm 0,1\end{array}$ & $\begin{array}{c}0,5 \\
\pm 0,0\end{array}$ & $\begin{array}{c}0,2 \\
\pm 0,0\end{array}$ & $\begin{array}{c}0,3 \\
\pm 0,0\end{array}$ & $\begin{array}{c}0,3 \\
\pm 0,0\end{array}$ & $\begin{array}{l}5,3 \\
\pm 0,2\end{array}$ \\
\hline $\begin{array}{l}\text { Россия, Азиатская часть (Памяти } \\
\text { Юдина, и-144680, ОмГАУ 90, и-144683, } \\
\text { Тюменская 25, и-146788, Тепсей, } \\
\text { и-146738) }\end{array}$ & $\begin{array}{c}0,3 \\
\pm 0,0\end{array}$ & $\begin{array}{c}1,4 \\
\pm 0,0\end{array}$ & $\begin{array}{c}1,6 \\
\pm 0,0\end{array}$ & $\begin{array}{c}3,6 \\
\pm 0,1\end{array}$ & $\begin{array}{c}0,5 \\
\pm 0,0\end{array}$ & $\begin{array}{c}0,4 \\
\pm 0,1\end{array}$ & $\begin{array}{c}0,4 \\
\pm 0,0\end{array}$ & $\begin{array}{c}0,3 \\
\pm 0,0\end{array}$ & $\begin{array}{l}5,6 \\
\pm 0,3\end{array}$ \\
\hline $\begin{array}{l}\text { Восточная Европа (Banti, и-620574, } \\
\text { Sirael, и-620336, Septima, и-620337, } \\
\text { Seance, и-620338) }\end{array}$ & $\begin{array}{c}0,4 \\
\pm 0,0\end{array}$ & $\begin{array}{c}1,2 \\
\pm 0,0\end{array}$ & $\begin{array}{c}1,2 \\
\pm 0,0\end{array}$ & $\begin{array}{c}3,9 \\
\pm 0,1\end{array}$ & $\begin{array}{c}0,5 \\
\pm 0,0\end{array}$ & $\begin{array}{c}0,049 \\
\pm 0,002\end{array}$ & $\begin{array}{c}0,5 \\
\pm 0,1\end{array}$ & $\begin{array}{c}0,3 \\
\pm 0,0\end{array}$ & $\begin{array}{l}4,2 \\
\pm 0,2\end{array}$ \\
\hline $\begin{array}{l}\text { Восточная, Юго-Восточная Азия } \\
\text { (Ke Quan, к-618040, Cao Yuan 1 Hao, } \\
\text { к-618046, Zhang Chun 9 Hao, к-618062, } \\
\text { Xin Chun 2 Hao, к-618132) }\end{array}$ & $\begin{array}{c}0,00018 \\
\pm 0,00001\end{array}$ & $\begin{array}{c}1,2 \\
\pm 0,0\end{array}$ & $\begin{array}{c}1,4 \\
\pm 0,0\end{array}$ & $\begin{array}{c}4,1 \\
\pm 0,3\end{array}$ & $\begin{array}{c}0,6 \\
\pm 0,1\end{array}$ & $\begin{array}{c}0,1 \\
\pm 0,0\end{array}$ & $\begin{array}{c}0,2 \\
\pm 0,0\end{array}$ & $\begin{array}{c}0,3 \\
\pm 0,0\end{array}$ & $\begin{array}{c}5,8 \\
\pm 0,2\end{array}$ \\
\hline $\begin{array}{l}\text { Австралия и Океания (Thatcher, } \\
\text { и-614386, K 1483, и-614292, CS 2A/2M, } \\
\text { к-614296, Line S, и-614254, W 2402, } \\
\text { к-614257) }\end{array}$ & $\begin{array}{c}0,00027 \\
\pm 0,00001\end{array}$ & $\begin{array}{c}1,4 \\
\pm 0,0\end{array}$ & $\begin{array}{c}1,4 \\
\pm 0,0\end{array}$ & $\begin{array}{c}3,5 \\
\pm 0,1\end{array}$ & $\begin{array}{c}0,4 \\
\pm 0,0\end{array}$ & $\begin{array}{c}0,2 \\
\pm 0,0\end{array}$ & $\begin{array}{c}0,2 \\
\pm 0,0\end{array}$ & $\begin{array}{c}0,3 \\
\pm 0,0\end{array}$ & $\begin{array}{l}4,6 \\
\pm 0,2\end{array}$ \\
\hline $\begin{array}{l}\text { Северная и Центральная Америка } \\
\text { (Alikat, к-616270, RL 6001, к-616297, } \\
\text { M 77-1140, к-616339, 93-11-2-3-2, } \\
\text { к-616486, UI Lochsa, к-616500) }\end{array}$ & $\begin{array}{c}0,00032 \\
\pm 0,00002\end{array}$ & $\begin{array}{c}1,2 \\
\pm 0,1\end{array}$ & $\begin{array}{c}1,3 \\
\pm 0,0\end{array}$ & $\begin{array}{c}3,4 \\
\pm 0,0\end{array}$ & $\begin{array}{c}0,5 \\
\pm 0,1\end{array}$ & $\begin{array}{c}0,1 \\
\pm 0,0\end{array}$ & $\begin{array}{c}1,1 \\
\pm 0,3\end{array}$ & $\begin{array}{c}0,3 \\
\pm 0,0\end{array}$ & $\begin{array}{l}4,8 \\
\pm 0,2\end{array}$ \\
\hline $\begin{array}{l}\text { Северная Европа (WW } 14069 \text {, } \\
\text { к-52786, WW 16151, к-52790 }\end{array}$ & $\begin{array}{l}0,0002 \\
\pm 0,0001\end{array}$ & $\begin{array}{c}0,9 \\
\pm 0,1\end{array}$ & $\begin{array}{c}1,2 \\
\pm 0,1\end{array}$ & $\begin{array}{c}4,4 \\
\pm 0,4\end{array}$ & $\begin{array}{c}0,7 \\
\pm 0,0\end{array}$ & $\begin{array}{c}0,2 \\
\pm 0,1\end{array}$ & $\begin{array}{c}0,4 \\
\pm 0,0\end{array}$ & $\begin{array}{c}0,3 \\
\pm 0,1\end{array}$ & $\begin{array}{l}6,3 \\
\pm 0,6\end{array}$ \\
\hline
\end{tabular}




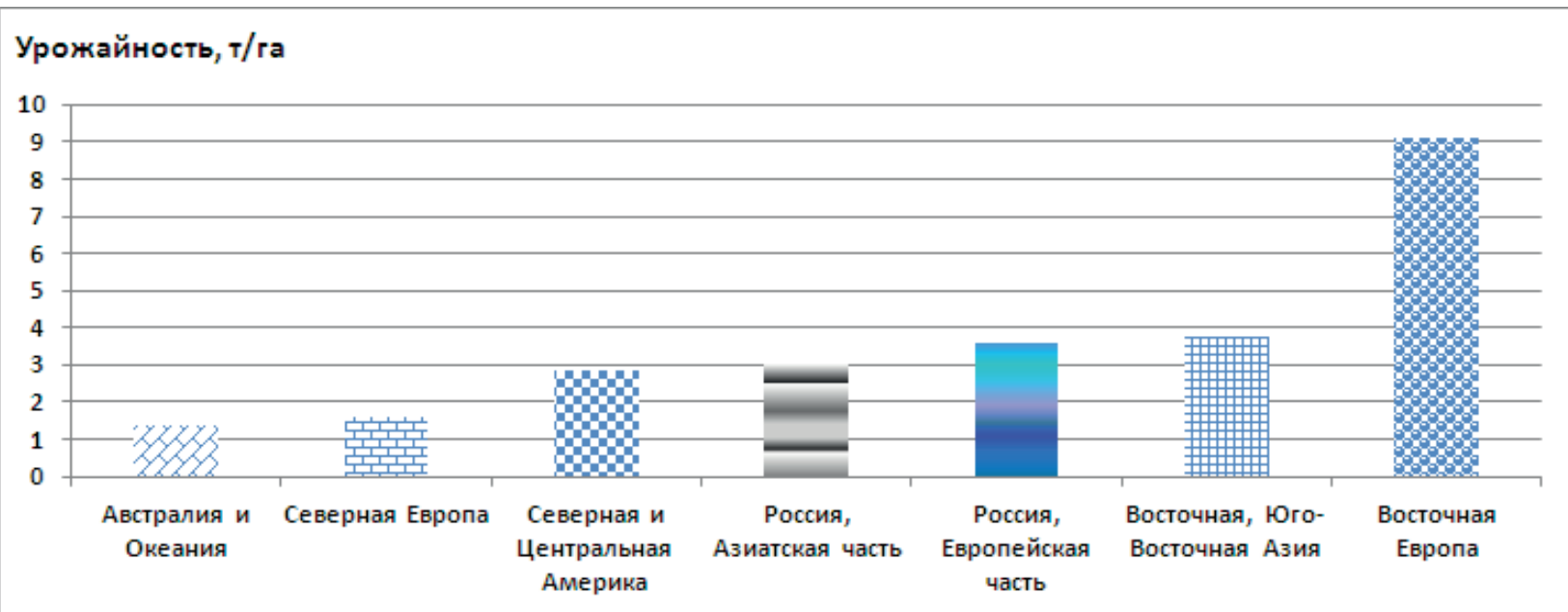

Рис. 3. Потенциальная урожайность яровой мягкой пшеницы различного происхождения

Юдина, и-144680; ОмГАУ 90, и-144683; Тюменская 25, и-146788; Тепсей, и-146738), а также из Восточной, Юго-Восточной Азии (Ke Quan, и-618040; Сао Yuan 1 Нао, и-618046; Zhang Chun 9 Нао, и-618062; Xin Chun 2 Нао, и-618132). Масса 1000 зерен составила: $38,0 \pm 0,8,40,3 \pm 0,79$ и 39,0 $\pm 1,1$ г соответственно.

Сорта яровой мягкой пшеницы, полученные из Азиатской части РФ, в отличие от образцов из Европейской части РФ, характеризовались существенно большими концентрациями в зерне Са (на 23,7\%); Со (на $39,8 \%$ ); $\mathrm{Bi}$ (на 184,8\%) и достоверно меньшим значением Sc (на 12,4\%). Сорта пшеницы, интродуцированные из Восточной, Юго-Восточной Азии, отличались достоверно большим содержанием $\mathrm{Mn}$ (на $30,1 \%$ ); $\mathrm{Bi}$ (на $85,6 \%$ ) и меньшими значениями $\mathrm{Na}$ (на 30,3\%); $\mathrm{Al}$ (на 33,5\%); Cu (на 16,7\%); $\mathrm{Se}$ (на 33,5\%); Mo (на 24,55\%); $\mathrm{Pb}$ (на 45,1\%); Sc (на 27,3\%).

Результаты определения коэффициентов ранговой корреляции Спирмена между показателями элементного состава зерна разных сортов пшеницы, показателями структуры урожая и повреждением пьявицей приведены в табл. 2.

На основании данных табл. 2 влияние разных элементов на состояние растений можно оценивать по соотношению его последствий как для самого растения, так и для его вредителей. Необходимо сразу оговорить, что эти оценки и выводы могут быть справедливыми только для тех диапазонов содержания изученных элементов в зерне, которые не выходят за пределы значений, найденных в исследованных образцах.

В этом смысле безусловно положительным можно считать действие калия, а также микроэлементов - меди и молибдена, уровни которых показывают прямую корреляцию с показателями структуры урожая (за исключением общей и продуктивной кустистости) и не коррелируют с повреждением листьев пьявицей. Эффективность использования калийных удобрений в растениеводстве хорошо известна [24].

Уровни хрома, скандия и кобальта, по данным табл. 2, положительно коррелируют с комплексом показателей структуры урожая. Увеличение содержания хрома в зерне обратно коррелировало с повреждением листьев пьявицей, а увеличение содержания скандия и кобальта усиливало повреждение растений вредителем. Положительное действие $\mathrm{Cr}$ на рост растений было отмечено и в других экспериментах $[1,6]$.
В некоторых работах приводятся данные о положительном влиянии соединений скандия на урожайность сельскохозяйственных культур. Использование сульфата скандия в качестве микроудобрения повышало всхожесть семян пшеницы и увеличивало на $13 \%$ прирост сухого вещества данной культуры, а также подсолнечника, кукурузы, гороха, сахарной свеклы и других растений [22].

Примечательно действие селена, которое, положительно сказываясь на некоторых, хотя и не всех показателях структуры урожая, в то же время подавляет эффекты вредителя. Содержание селена в зерне пшеницы, выращенной в России, колеблется в пределах от 10 до 240 мкг/кг [25]. В работе [7] отмечено, что в зерне яровой пшеницы, полученной с опытных полей Подмосковья, содержание селена составляет 80-85 мкг/кг. В нашем опыте в зернах исследуемых сортов содержание селена составило $94,39 \pm 23,39$ мкг/кг.

Тяжелые металлы (Pb, Bi, Cd, Mn) отрицательно сказываются не только на растении, но и на его вредителе, как и следует ожидать по причине их известной общей токсичности $[15,16]$. Ту же однонаправленность демонстрирует и магний. Из десяти элементов, у которых отмечена отрицательная корреляция с повреждением растений пьявицей, только у четырех $(\mathrm{Cu}, \mathrm{Mo}, \mathrm{Se}, \mathrm{Cr})$ корреляция с показателями продуктивности положительная.

Вывод о том, что действие $\mathrm{Cd}$ и $\mathrm{Pb}$ на пшеницу в целом отрицательное, согласуется с результатами работы [11], где отмечено отрицательное влияние этих элементов на рост и дифференциацию стеблевых апикальных меристем, темпы органогенеза и физиологические процессы и работу листового аппарата злаков.

Действие кальция на пшеницу выглядит неоднозначным. При этом корреляции уровня его содержания с повреждением листьев пьявицей отсутствует. Известно, что ионы Са принимают участие в регуляции многих стрессовых реакций растительных клеток, в частности, в активации каталазы [13, 14, 23].

Влияние талия и мышьяка на пшеницу однозначно неблагоприятное. Неблагоприятными факторами для пшеницы следует признать и эффекты повышения уровней натрия и алюминия, которые в свойственных для изученных образов диапазонах концентраций отрицательно коррелируют с показателями структуры урожая пшеницы (за исключением общей 
Значимые коэффициенты ранговой корреляции Спирмена $(\mathrm{P}<0,05)$ между показателями элементного состава зерна яровой пшеницы, продуктивности пшеницы и поврежденности ее листьев пьявицей

\begin{tabular}{|c|c|c|c|c|c|c|c|c|c|c|c|c|c|}
\hline 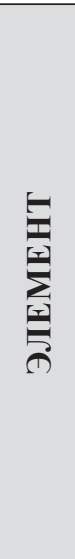 & 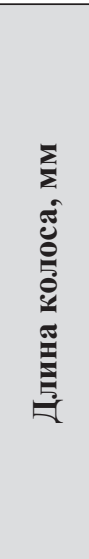 & 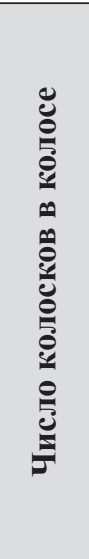 & 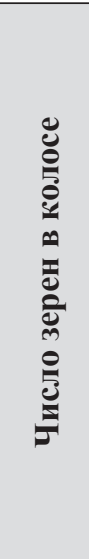 & 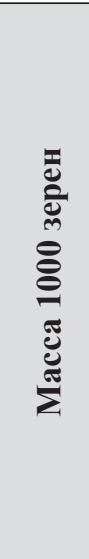 & 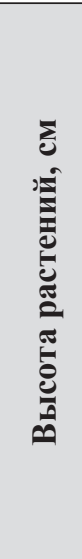 & 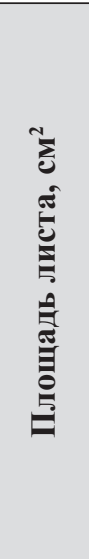 & 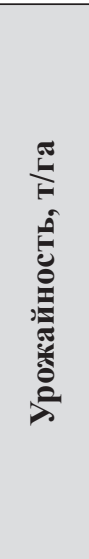 & 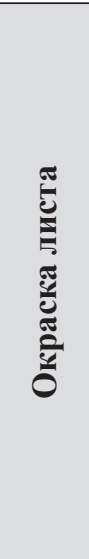 & 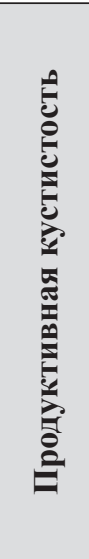 & 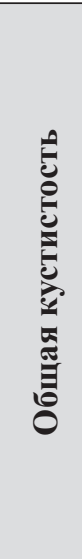 & 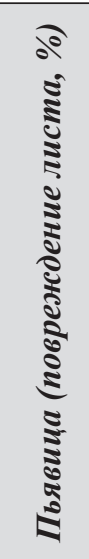 & 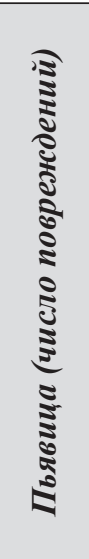 & 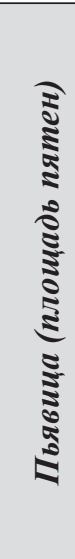 \\
\hline K & $+0,5$ & $+0,6$ & $+0,7$ & & $+0,5$ & $+0,6$ & $+0,5$ & $+0,6$ & $+0,6$ & $+0,6$ & & & \\
\hline $\mathbf{C u}$ & $+0,3$ & & & $+0,6$ & $+0,7$ & & & $+0,4$ & $-0,3$ & $-0,3$ & $-0,4$ & $-0,4$ & $-0,6$ \\
\hline Mo & & $+0,5$ & & $+0,5$ & & & & $+0,6$ & $-0,4$ & $-0,4$ & $-0,5$ & $-0,5$ & $-0,5$ \\
\hline $\mathrm{Se}$ & & & $-0,5$ & $+0,5$ & $+0,5$ & $+0,5$ & $-0,4$ & & $-0,5$ & $-0,5$ & $-0,5$ & $-0,3$ & $-0,3$ \\
\hline $\mathrm{Cr}$ & & $+0,8$ & $+0,3$ & & & $+0,4$ & & & & & $-0,4$ & $-0,3$ & $-0,3$ \\
\hline $\mathrm{Fe}$ & & & $-0,7$ & $-0,4$ & $+0,5$ & & & & & & & & \\
\hline Sc & & & $+0,3$ & & $\begin{array}{l}+0,6 \\
\end{array}$ & & & & $+0,7$ & $\begin{array}{r}+0,7 \\
\end{array}$ & $+0,7$ & $+0,6$ & $+0,6$ \\
\hline $\mathbf{P b}$ & $-0,4$ & $-0,4$ & & & $-0,7$ & $-0,5$ & & & & & $-0,6$ & $-0,7$ & $-0,6$ \\
\hline Cd & & $-0,6$ & & & & $-0,8$ & & & & & $-0,7$ & $-0,4$ & $-0,6$ \\
\hline $\mathbf{B i}$ & & $-0,5$ & & & & & & & & & $-0,6$ & $-0,7$ & $-0,7$ \\
\hline Mn & & & $-0,4$ & & & & & & $-0,4$ & $-0,4$ & $-0,8$ & $-0,8$ & $-0,8$ \\
\hline $\mathrm{Mg}$ & $-0,5$ & $-0,6$ & & $-0,8$ & & $-0,7$ & & & $-0,4$ & $-0,4$ & $-0,4$ & $-0,4$ & $-0,5$ \\
\hline $\mathbf{C a}$ & & & & $-0,8$ & & & & $-0,3$ & $+0,6$ & $+0,6$ & & & \\
\hline $\mathbf{B a}$ & & & & $-0,7$ & & & & & $+0,7$ & $+0,6$ & $-0,5$ & $-0,6$ & $-0,4$ \\
\hline $\mathbf{N i}$ & & & & $+0,6$ & & & $-0,3$ & $-0,7$ & $-0,4$ & & & & \\
\hline Co & & & $+0,3$ & $-0,4$ & & & $+0,4$ & & $+0,4$ & $+0,3$ & $+0,3$ & $+0,3$ & $+0,4$ \\
\hline $\mathrm{Tl}$ & $-0,5$ & $-0,5$ & & & $-0,5$ & $-0,6$ & & & & & & & \\
\hline As & $-0,4$ & $-0,4$ & $-0,7$ & & & & $-0,6$ & & & & & & \\
\hline $\mathbf{N a}$ & $-0,4$ & & $-0,6$ & & & & & & $+0,4$ & $\begin{array}{l}+0,3 \\
\end{array}$ & $+0,7$ & $+0,7$ & $+0,6$ \\
\hline $\mathbf{A l}$ & $-0,5$ & & $-0,4$ & & & & & & $+0,4$ & $+0,4$ & $+0,8$ & $+0,8$ & $+0,8$ \\
\hline
\end{tabular}

и продуктивной кустистости) и при этом положительно - с показателями ее повреждения пьявицей. Возможно, что в этих случаях активизация пьявицы оказывается одним из факторов отрицательной связи между уровнями данных элементов и показателями структуры урожая.

\section{Выводы}

Проведенные исследования свидетельствуют о том, что показатели структуры урожайности яровой мягкой пшеницы и ее устойчивости к вредителям зависят от содержания металлов и металлоидов. Отмечена положительная связь между содержанием калия, скандия, кобальта в зернах сортов и линий пшеницы на большинство рассмотренных показателей урожайности пшеницы. Действие магния, натрия, кальция, бария, марганца, меди, никеля, селена, молибдена на пшеницу выглядит неоднозначным.
Выявлено снижение повреждения листьев сортов и линий пшеницы личинками пьявицы обыкновенной с увеличением содержания в зернах магния, марганца, меди, молибдена, селена, хрома, кадмия, свинца, висмута, бария. Некоторые из этих элементов (свиней, кадмий, висмут, марганец) токсичны для самых разных живых организмов, о чем может свидетельствовать и снижение показателей продуктивности пшеницы при увеличении содержания данных элементов в зерне.

Результаты работы могут быть использованы в практике общего земледелия, защиты растений и экологии. Выявленные зависимости между поврежденностью растений личинками пьявицы и элементным составом пшеницы позволяют рекомендовать личинок пьявицы обыкновенной в качестве тест-объектов для биотестирования агроэкосистем на наличие тяжелых металлов. 


\section{Литература}

1. Арнон Д. Микроэлементы. - М. : ИЛ, 1962. - C. 9-40.

2. Артюшин А.М., Дерюгин И.П., Кулюкин А.Н., Ягодин Б.А. Удобрение в интенсивных технологиях возделывания сельскохозяйственных культур. - М. : Агропромиздат, 1991. -223 c.

3. Больиаков В.А. Аэротехногенное загрязнение почвенного покрова тяжелыми металлами: источники, масштабы, рекультивация. М., 1993. - С. 22-28.

4. Воронков Д.И., Яичкин В.Н. Продуктивность и агроэкологическая оценка качества основной продукции яровой мягкой пшеницы на различных агрохимических фонах в условиях Оренбургской области // Вестник ОГУ. 2006. - № 12. - С. 59-61.

5. Гуслии И.С., Шапиро И.Д. Красногрудая пьявица // Методические рекомендации по оценке устойчивости сельскохозяйственных культур к вредителям (ред. Шапиро И.Д.). Л. : ВИЗР, 1978. - С. 79-97.

6. Добровольский О.К. Биологическое действие микроэлементов в связи с их положением в периодической системе Д.И. Менделеева // Биогеохимия растений. - Вып. 2. - Улан-Удэ, 1969. - С. 29-38.

7. Долгодворова А.П., Воронина Л.П. Влияние селеновых удобрений на рост и развитие ярового ячменя // Питание растений. - 2012. № 3.- C. 15-19.

8. Захаренко В.А., Захаренко А.В. Экономический аспект применения пестицидов в современном земледелии России // Российский химический журн. - 2005. - T. XLIX. - № 3. - C. 55-63.

9. Зуев Е.В., Колесников Л.Е., Колесникова Ю.Р. Анализ коллекции яровой мягкой пшеницы по селекционно-ценным признакам и устойчивости к болезням в условиях СевероЗапада РФ // Известия Санкт-Петербургского государственного аграрного университета. 2012. - № 28. - C. 37-42.

10. Ильин В.Б. Тяжелые металлы в системе почва-растение. - М. : Наука, 1991. - 151 с.

11. Казнина Н.М. Влияние свинца и кадмия на рост, развитие и некоторые другие физиологические процессы однолетних злаков. - Автореф. дисс. ... канд. биол. наук. - Петрозаводск, 2003. $-23 \mathrm{c}$.

12. Колесникова Ю.Р. Влияние агроэкологических факторов на продуктивность яровой мягкой пшеницы и развитие возбудителей болезней в условиях Северо-Запада РФ. - Автореф. дисс. ... канд. с.-х. наук. - СПб., 2012. - 22 с.

13. Колупаев Ю. Е., Карпец Ю. В. Регуляция активности каталазы в колеоптилях пшеницы: возможная роль ионов $\mathrm{Ca}^{2+}$ и кальмодулина // Вісник харківського національного аграрного університету. Сер. біол. - 2008. - Вип. 1. - С. 15-21.

14. Колупаев Ю.Е., Акинина Г.Е., Мокроусов $A . B$. Индукция теплоустойчивости колеоптилей пшеницы ионами кальция и ее связь с окислительным стрессом // Физиология растений. - 2005. - Т. 52. - С. 227-232.
15. Кольс О.Е., Ложкина Н.И., Прокуратова А.С., Калиненко Н.А. Развитие листостеблевых болезней зерновых культур при длительном применении средств химизации в южной лесостепи Западной Сибири // Сельскохозяйственные науки. Фундаментальные исследования. - 2006. - № 8. - С. 66-68.

16. Медведев П.В., Федотов В.А. Исследование влияния природно-географических и сортовых факторов на накопление тяжелых металлов яровой пшеницей // Вестник ОГУ. 2009. - № 6. - С. 222-226.

17. Мережко А.Ф., Удачин Р.А., Зуев В.Е., Филотенко А.А., Сербин А.А., Ляпунова О.А., Косов В.Ю., Куркиев У.К., Охотникова Т.В., Наврузбеков Н.А., Богуславский Р.Л., Абдуллаева А.К., Чикида Н.Н., Митрофанова О.П., Потокина C.A. Пополнение, сохранение в живом виде и изучение мировой коллекции пшеницы, эгилопса и тритикале. Методические указания. - СПб. : ВИР, 1999. - С. 32-35.

18. Оберлис Д., Харланд Б., Скальньй А. Биологическая роль макро- и микроэлементов у человека и животных. - СПб. : Наука, 2008. - 542 с.

19. Рязанцев Н.В., Курочкин Н.Н., Иманова Д.И., Иманова И.И., Павлова Т.И. Влияние микроэлементов на урожайность озимой пшеницы // Специалисты АПК нового поколения. Материалы IV Всероссийской научно-практической конференции. - Саратов, 2010. С. $187-190$.

20. Сокаев K.E. Содержание тяжелых металлов в почвах Северной Осетии // Вестник МАНЭБ. - 2002. - Т. 7, № 50. - С. 95-100.

21. Танюхина О.Н., Подгорная Е.Б., Колесников Л.Е., Ланге Е.К., Бурова О.И. Применение комплексной эколого-гигиенической оценки водной химической нагрузки в районах размещения химически-опасных объектов и ее влияние на здоровье населения // Медико-биологические аспекты обеспечения химической безопасности Российской Федерации. Сб. трудов Всероссийского симпозиума, посвященного 50-летию со дня основания ФГУП НИИ ГПЭЧ ФМБА России. - СПб. : Элби-СПб., 2012. - С. 248-250.

22. Фомина А.В., Назаров В.А., Назаров Л.С., Подгорнова T.C. Роль редкоземельных элементов в жизни растений и перспектива их применения в растениеводстве. Специалисты АПК нового поколения. Материалы IV Всероссийской научно-практической конференции. - Caратов, 2010. - С. 237-238.

23. Шугалей И. В., Гарабаджиу А. В., Илюшин М. А., Судариков А.М. Некоторые аспекты влияния алюминия и его соединений на живые организмы // Экологическая химия. - 2012. T. 21. - № 3. - C. 172-186.

24. Якименко В.Н., Носов В.В. Эффективность применения калийных удобрений в Западной Сибири // Питание растений. - 2012. № 1. - C. 2-4.

25. Golubkina N.A. Selenium accumulation by cereals in Russia // Russian Agricultural Sciences. 2007. - Vol. 33. - P. 288-291. 